Saudi Journal of Economics and Finance

Abbreviated Key Title: Saudi J Econ Fin ISSN 2523-9414 (Print) | ISSN 2523-6563 (Online) Scholars Middle East Publishers, Dubai, United Arab Emirates Journal homepage: http://saudijournals.com/sjef/

Original Research Article

\title{
Performance of Employees in Service in Agency Staffing and Human Resources Development District North Barito \\ Antoni*
}

Master Program of Government Science, Lambung Mangkurat University, Banjarmasin, Indonesia

\author{
DOI: $10.36348 /$ sjef.2019.v03i11.008 \\ | Received: 09.11.2019 | Accepted: 15.11.2019 | Published: 19.11.2019 \\ *Corresponding author: Antoni
}

\section{Abstract}

Regional Employment is a system or procedure set out in the legislation. The subject covers diverse aspects as part of a subsystem of the national employment system. This study aimed to describe the performance of government services in the promotion of the Civil Service Agency for Employment and Human Resources Development (BKPSDM) North Barito regency. A qualitative approach was used to describe the research. The descriptive method was chosen to explore the entire data holistically. Data collected three stages; observation, interviews, and documentation. Miles and Huberman models used as part of interactive analysis. The results of the study are described that BKPSDM services already showing good service. This was followed by several indicators, namely; Vision and mission as the driving performance, focus on the success and determination of value, internal communications along with stakeholders, flexibility, empowering employees and improving the competence of workers, and the competence of performance. However, the implementation of the service is still found a significant obstacle. The constraints associated with the lack of facilities and infrastructure owned. So the service is often done manually.

Keywords: Personnel area, promotions, and services.

Copyright @ 2019: This is an open-access article distributed under the terms of the Creative Commons Attribution license which permits unrestricted use, distribution, and reproduction in any medium for non-commercial use (NonCommercial, or CC-BY-NC) provided the original author and source are credited.

\section{PRELIMINARY}

Civil Service Agency and Human Resources Development (BKPSDM) is a local government organization that has a major role to manage the management of personnel and services to civil servants in the region concerning staffing, both BKD and Employment Agency and Human Resources Development (BKPSDM) Regency / City. One is the Human Resources Agency and Human Resources Development (BKPSDM) North Barito district, Central Kalimantan Province.

Based on the North Barito Regency Regulation No. 38 the Year 2016 concerning Organizational Structure and Work of North Barito regency. The position of Civil Service Agency and Human Resources Development (BKPSDM) has a fundamental duty and function as supporting elements local government areas of personnel management Civil Service in this case regarding formation of personnel administration, procurement and personnel transfers, employee welfare and development of the discipline and dismissal as well as career development employees, including the promotion of employees.
Based on data from Employment Agency and Human Resources Development (BKPSDM) Barito Utara Number of civil servants in North Barito regency until February 2018 amounted to 3,994 people. Then the plan will grow back with the addition that will be accepted for admission employees Region 2018 Months many as 300 people for the formation of CPNS consisting of teachers, health workers, and technical personnel. That is BKPSDM North Barito regency always serves the interests of civil servants in terms of the interests of local civil service, including the promotion as many as 4,294 civil servants.

Management of the promotion is part of the job BKPSDM, demanding a good performance. This demand requires an earnest effort to make it happen because the performance of the current government bureaucracy is considered still show high performance. This marked the low quality of services provided to the public bureaucrats and this also often blamed as one of the factors responsible for the decline of this country [1]. This concern also applies to BKPSDM North Barito regency in the framework of services for local civil servants. This article aims to describe the performance of services in respect of the Government in the promotion of the Civil Service Agency for Employment 
and Human Resources Development (BKPSDM) North Barito district, both concerning the proposal promotion services,

\section{RESEARCH METHODS}

The approach taken in this study is qualitative. The qualitative method is a research procedure that produces descriptive data in the form of written or spoken the word of the people and observed behavior. The approach is directed at the background and individual holistic or whole [2]. The study aims to describe the government services in the promotion of civil servants provided by the Personnel Board and Human Resources Development in the Field of Formation, Mutation, Retirement and Information Officer of the PNS North Barito regency. The research location Personnel and Human Resources Management Agency of North Barito regency. The research instrument is an instrument at the time of the study using a method [3]. In the tradition of qualitative research, the instrument is the interview, scalable, and documents to support the author's use of data. The informant described as follows:

Table-1: Informant Research

\begin{tabular}{|c|l|c|}
\hline No. & \multicolumn{1}{|c|}{ Informant } & Amount \\
\hline 1 & Head of Human Resources and Human Resources Development & 1 \\
\hline 2 & $\begin{array}{l}\text { Secretary of State for Employment and Human Resources } \\
\text { Development }\end{array}$ & 1 \\
\hline 3 & $\begin{array}{l}\text { Head Formation, Mutation, Retirement and Employee } \\
\text { Information }\end{array}$ & 1 \\
\hline 4 & $\begin{array}{l}\text { Subbid Head Movements } \\
\text { promotion }\end{array}$ \\
\hline
\end{tabular}

Source: Adapted Researcher, 2018

Data collected by three stages; 1) The interview as a process of questions and answers between two or more people directly confront or through the media, 2) observation in the study site to describe the activity going on, and 3) Documentation tracked the source of data on the number of employees, facilities owned. Data analysis using the flow of activities as proposed by Miles and Huberman [4] namely; data reduction, data display, and verification [4]. Examination of the validity of data based on certain criteria. So do several stages; 1 ). The extension of the observations to pay attention to something more accurate, detailed and in-depth, also prove the statement delivered via interviews.

\section{RESULTS AND DISCUSSION \\ Employment and Human Resources} Development Agency (BKPSDM) North Barito regency government as the leading Sector in all matters of personnel administration environment of North Barito regency government of course also have a service function following its duties. Essential services for the organization BKPSDM North Barito district itself, to achieve organizational goals. Besides, civil servants expect excellent service-related interests and concerns as civil servant status.

Services are activities that are invisible (intangible) that occurs as a result of the interaction between consumers and employees or other matters provided by the company/organization of service providers that are intended to solve the problems that are owned by consumers or customers [5]. One form of ministry BKPSDM North Barito district is in the process of promotion services (KP) for employees in the North Barito regency government environment. As of promotion stipulated in Government Regulation No. 12 of 2002 made clear that the period of the Civil Service promotion is set on April 1 and October 1 of each year.

Of promotion is an award given on work performance and dedication of the Civil Service to the State concerned. Besides, promotion is also intended as an encouragement to civil servants to further improve work performance and dedication. Of promotion is a tribute and every new award has a value of promotion if it is given the right person and right on time [6]. Additionally, Ranks which is an award given to a civil servant (PNS) or work performance and dedication as an employee would be devastating to the existing civil servants, where the Ranks they have certainly will affect the career development and will also affect the salary increase for civil servants or wage growth is concerned. BKPSDM services through its unit in respect of promotion a decisive part also cumulative service performance of the unit in BKPSDM. Therefore, the performance of BKPSDM referred to in the service promoted on performance indicators, as follows:

\section{Vision Mission for Driving Performance}

Vision and mission-critical for the survival of the organization, especially in implementing management systems in the workplace. Strategic planning is used to realize the vision and mission of the organization and share the resources required to achieve them. An organization initially have a goal or the 
ultimate goal to be achieved in the long term so-called vision, and then to realize the vision of the organization is determined. Performance is an overview of the level of achievement of the program or policy in achieving the goals, objectives, vision and mission of the organization that poured through the strategic planning of an organization providing services, including BKPSDM North Barito district provides services for a promotion of the civil servants in the Government of North Barito regency.

The existence of Civil Service Agency and Human Resources Development stated in Barito Utara Barito Utara District Regulation No. 2 of 2016 on the Establishment and composition of the regional North Barito regency. In these Regulations that the position of Duty and Function of Personnel and Human Resources Management Agency of North Barito regency a support element in the field of Local Government employment, education and training, In connection with the tasks ahead are full of challenges and lead to improvements in the effectiveness of performance in carrying out the task of good government (good governance) [7]. Civil Service Agency and Human Resources Development North Barito regency is SKPD that are technically operational and administrative responsible to the Regent through the Local Secretary North Barito district, where the activities of the organization's performance, units and employees BKPSDM oriented Vision and programs determined the area to then be adjusted BKPSDM mission vision as the driving performance of the organization.

Vision Personnel and Human Resources Management Agency of North Barito regency is "The Apparatus the Moral Resources, Professional and Dignified in Providing Excellent Service". The vision associated with the resulting performance Personnel and Human Resources Management Agency of North Barito regency as an institution engaged and responsible field employment, education, and training, including the management of promotion of civil servants.

North Barito district BKPSDM performance is expected to show gains of a program at a specific work unit within a certain period. In this case, service promotion, in which at least can show the performance evaluation assessment of the success/failure of the implementation of activities following the means and objectives of the mission and programs that have been established in the planning vision.

Therefore, the organization's performance evaluation is also to provide an assessment of the achievements of a program/activity and development policies. Increasing the capacity of personnel resources, especially in service and awareness BKPSDM apparatus is characterized by increasing care facilities, increasing the welfare of employees, the establishment of the rule of law, the growing culture of good performance, increasing quality of the religious and cultural resistance, as well as the implementation of services that are performing well.

\section{Focus Success and Determination of Value (Focus on Result and Creating Value)}

Judging from the performance criteria of the concept of service of one of them is the result of the services or products of services performed. It is intended to let users access the service easily in the service of the implementers. It is important for BKPSDM North Barito regency as the leading sector in realizing the promotion of civil servants' service performance. At least be an example for civil servants who use services which they are a public service. There are some things in pointer regarding the determination result of success, as follows:

1. The results of the performance have involved all the civil servants in BKPSDM.

View of top management, middle and lower-level management, service performance results of promotion involving staff. Though still a small part contributed. Promotion management performance standards of routine daily, weekly, monthly accordingly based on the prevailing regulations. This is confirmed by the statement of the Head of Formation, Mutation, Retirement, and INKA stating that the standard of performance under the Act and Regulation are available.

2. Seeing Results and Measuring Performance Standards.

How to measure performance according to a statement of leadership, good secretaries, heads of Formation, Mutation, Retirement and INKA and head of the Division Mutations still limited in accuracy and speed of turnaround time. The promotion of a timely and proper person is considered a good performance. Concerning public services generated by the organization's performance shows that the community is the customer, and the organization has been fused when the two interact [8].

From the concept of quality criteria intended for easy service users in accessing services. Party executive seeks the achievement of service performance which absorbs the completion of all users of existing services is also a manifestation of the leading quality of service.

\section{Shared Internal Stakeholder Communications}

Communication is needed so that decisionmakers and implementers of decisions in an organization are consistent in carrying out any implementation of services implemented by an organization. There are three variables in the measurement of communication, among others; Transmission or distribution of Communication, Clarity, and Consistency [9]. Perception communication 
is the determination of each communication center. In this regard, the perception that rarely has perfect alignment with reality. Therefore one must always consider the extent of the difference (range disparity) between reality and perception [10]. Achievement of service performance is the main target to be achieved by BKPSDM North Barito district so Pula civil service promotion.

The results of this study Identification of the location, direction of policy in line with their internal services performed by BKPSDM North Barito regency. Services Internal is meant here is the commitment BKPSDM North Barito district that consider employee is very important in realizing the external service of high quality for the execution of service rank of civil servants, other than that it is done in order to create employee satisfaction as the services of which if employees are satisfied against BKPSDM North Barito district would also increase employee loyalty towards BKPSDM North Barito regency.

\section{Flexibility}

of promotion can be said to be a reward given to employees to assume greater responsibility, as for the mobilization of the employees themselves constitute a shift or over from the old place to place that any new form of promotion promotional Civil Service is set on April 1 and October 1 of each year, except for some types of promotions specifically defined enactment [8]. Promotion here consists of three types: (1) Rank Promotion Regular, (2) promotion of choice, and (3) promotion dedication, This regular promotions given to civil servants, including employees doing prior learning task and not positions structural or certain functional positions, fully employed outside the central institution and do not occupy leadership positions predetermined or certain positions.

Efforts BKPSDM North Barito regency in implementing services to employees who are members of the organization can be seen through the organization's management BKPSDM North Barito district is run in an open and flexible. The organization provides the opportunity for every employee to participate in contributing to organizational improvement efforts. Especiallyimplementation of civil service promotion does BKPSDM North Barito district through feedback and suggestions from employees. Management in North Barito regency BKPSDM done openly and flexibly is intended to always provide the best service for employees other work units that come into BKPSDM. BKPSDM external services and civil servants can be established a good working relationship and open so that they can participate by providing and suggestions will enter service conditions BKPSDM.pointer about flexibility related to service performance promotion BKPSDM North Barito district, among others:
1. Anticipation strategy change strategy Personnel and Human Resources Management Agency of North Barito regency in anticipation of changes that occur in the management of the promotion is to adjust to the change quickly, either derivative, the mechanisms, terms of promotion and so on. This strategy is supported by leadership. The staff also supports the statement that to anticipate changes nothing strategy, Just customize soon changes.

2. How do the changes made to Personnel and Human Resources Management Agency of North Barito regency in making changes to the satisfaction of those who served in the management of the promotion is to simplify the mechanism and quickly disseminate such changes, among others, with the replacement of program data?

3. Efforts to build the capacity to do Personnel Board and Human Resources Development Barito Utara District to build the organization's capacity concerning continuous service improvement, especially in the management of the promotion is to work within the rules to improve the quality of service.

4. How to create a high-performing organization structure. According to the leading BKPSDM, how BKPSDM North Barito regency creates a high organizational structure, especially in the management of the promotion is to create a lean organizational structure, less structure-function offset by the development of human resources.

5. How to design the appropriate organizational functions, Employment, and Human Resources Development Agency North Barito regency design organization according to the function of the organization is expected, especially in the management of the promotion is to develop and empower the Human Resources function in managing the rise BKPSDM rank,

\section{Empowering Employees and Workers Competency Enhancement}

Abilities and skills for the services of an organization have an important role to consummate good service. Every employee in an organization must have the ability and skills related to the fieldwork undertaken. Ability and skill have different meanings but both have a strong bond to have in every employee to perform the work according to the task at hand. The understanding of the ability itself is derived from the word capable of being in a relationship with a task/job can mean (adjective/state) task/work to produce goods or services as expected. While the skill itself is the ability of an employee in performing the task/job by using limbs and tools available [11].

Ability and skills possessed by employees at each job duties are expected to build the professionalism of the services of the existing in an 
organization especially governmental organization (bureaucracy) as a public service. It is also the point of optimization of bureaucracy very influenced by the professionalism of the bureaucracy. Where in the bureaucracy whose members are highly educated, knowledgeable and experienced adequate then the necessary bureaucratic nature different from the bureaucracy that most members are less educated, narrow horizons, and have very limited experience [7].

The division of duties is meant each staff becomes aware of the service personnel's basic tasks. Interest division of tasks through delegation of authority of the service implementation. Concierge service runs freely because it has been previously routed through the existing delegation of authority. Such conditions can certainly in the service process procedures, especially in the service process environment BKPSDM promotion of civil servants this North Barito regency. Attempts to avoid stiffness promotion services performed by BKPSDM North Barito regency is felt normal, and that an effort is also to motivate employees more efficient at work. Employment and Human Resources Development Agency North Barito district motivates employees to build and use all the potential to achieve the goal. The contribution of education and training in the achievement of organizational goals, the need for employees including development, learning, and progress career, Particularly in the management of large enough promotion.

Employment and Human Resources Development Agency Barito Utara District has never been an evaluation of Education and training as well as the connection with the Employee Development performance individuals and organizations in the management of promotions. Employment and Human Resources Development Agency North Barito district directs and urges the importance of using knowledge and skills in the implementation of management tasks promotions.

Promotion services according to existing regulations, carried out with the best. But the empowerment necessary infrastructure and facilities for the benefit of services, including promotion for every civil servant scope of North Barito regency government. In addition to requiring infrastructure support, the necessary resources human right in the field, Contributions Education and training in the achievement of organizational objectives, meet the needs of employees, including the development, learning, and progress career, Particularly in the management of promotions. However, the Civil Service Agency and Human Resources Development of North Barito regency need to evaluate education and training as well as staff development related to individual and organizational performance in the management of promotions.

\section{Competition Performance Improvement}

In North Barito BKPSDM organization, an achievement often rewarded in place work, and the employee with high-level ambitious to obtain position and power in the organization, behave and think that the best performance is obtained by defeating others. The best performance is obtained from the ability to motivate yourself, to achieve growth personal improve the quality and competence of themselves in the workplace. Achievement earned from defeating others through unhealthy ways. Interest groups are something that can make a person who is not qualified to get the achievement and promotion to a higher level.

Competition should be right for the right person. In a professional working environment, a competition highlighting the potential and capabilities of the best workers to help the organization, and improve organizational performance through effective collaboration culture. Thus, the organization does not allow conflicts and unfair competition to grow in self anybody. Each worker is given the enlightenment that competition is not something that is advance career individuals, but a collaboration that effectively renders individuals are performing joint contributions.

In North Barito BKPSDM in terms of the civil service promotion, competition in the workplace is explicitly not show competitions such as the above. But implicit unhealthy competition in accidental occur. Where the competition associated with revenue-raising efforts (extra money) out of income in the form of salaries and allowances of areas such as travel money services, activities operational and incentives. Competition in place the work is not intended to be personal is more aggressive, and less productive because of a conflict of competition. Competition in the workplace is so that each individual can contribute to the maximum through the quality and the potential to produce the best performance.

\section{Constraints Factor in Service Performance BKPSDM North Barito regency}

In general, the various causes of non-optimal performance of government organizations took place in various government organizations themselves and the condition continues when it is not recognized and corrected immediately. Improved performance of service to the community is not easy, because it is common knowledge that a lot of public disappointment with the services provided by the government so far. Performance constraints in-service promotion in North Barito regency BKPSDM seen several factors affect, among others:

\section{Role ambiguity,}

Employees (executor) faced with the issue of overlapping and unclear regulations which should be used as technical guidance and administration of such services; Law - Law No. 43 of 1999 on the subject Employment subject to Law - Law No. 05 of 2014 
concerning the State Civil Apparatus. In this case, since the Act ASN has not released the technical rules of the promotion, the promotion services still refer to the technical rules.

\section{Poor time job fit}

Based on the service process flow increase in rank number 12 of 2002 concerning civil servants of promotion, relating to these terms each period of the promotion have been written by BKPSDM North Barito district through a circular to all government environment agencies Barito Utara 4 months before the date of determination of promotion for every period. The purpose of this policy is to give a longer opportunity to propose the promotion of civil servants to avoid delays within the limits of a predetermined time. While the purpose of the requirement is disseminated through this circular is to allow workers to know that they must satisfy requirements without having to bother to come to BKPSDM North Barito regency.

But the spread of a circular relating to the implementation of this promotion has problems. This is especially true for teachers in Employment functional Barito Utara District Education Office and functional health. Problems occur where a civil servant in the organization is still difficult to access information about the promotion is only given in the form of a circular and the notice board at the organization. The number of teachers and teaching schedule that many are not doing the work every day to make the information too late to the concerned. Similarly, for paramedics who have a per shift and relatively busy with the task of health care.

\section{Poor technology job fit}

Employee performance is strongly influenced by the equipment and technology they use, as a result when the equipment and technology. Although BKPSDM North Barito district already uses Service Application System Officer (SAPK) which is a product of BKN, for its application in the area, especially in BKPSDM North Barito regency is still not maximized due to the unavailability of specific applications for the teacher or health worker accessing an application the. As for the proposal of promotion for the energy functional teachers and health workers, each year should be updated Credit Score they earn. This situation led to the implementation of the civil service promotion conducted by BKPSDM North Barito regency is done manually with the existing infrastructure.

\section{Inappropriatesupervisory control system}

Evaluation of organizational performance BKPSDM North Barito district is required to determine the extent of the organization's efforts achievements of the organization's performance, especially in the implementation of civil service promotion. Implementation of job evaluation, especially in the implementation of civil service conducted promotion of
Formation, Mutation, Retirement and INKA BKPSDM this North Barito district, stated in LAKIP BKPSDM North Barito district for each year. In this analysis described developments in the achievement of the goals and objectives following the policies, programs, and activities that are taken from the Final Achievement Value Performance Measurement. Besides, this evaluation is important because at this LAKIP outlines interest in the achievement of the performance program of activities in realizing the goals, Goals, strategic organization annually.

\section{CONCLUSION}

The performance of government services in promotion in the Civil Service Agency and Human Resources Development of North Barito regency is good. Seen from several performance indicators such as vision and mission as the driving performance of the organization, determination of the results achieved and focus on the achievements (focus on the result and creating value), communication with stakeholders (customer-driven - excellence) and internal organization, flexibility in service, empowerment employees as well as competition increased performance, where all the indicators point to the fact/data that have been good. Based on the workflow promotion of civil servants, the service of promotion is still manual and BKN based regional office/archipelago which is located in South Kalimantan Banjarbaru.

\section{REFERENCES}

1. Shi, Y., Lan, F., Matson, C., Mulligan, P., Whetstine, J. R., Cole, P. A., \& Shi, Y. (2004). Histone demethylation mediated by the nuclear amine oxidase homolog LSD1. Cell, 119(7), 941953.

2. Bungin, B. (2008). Analisis Data Penelitian Kualitatif. Jakarta: Raja Grafindo Persada.

3. Mulyana, D. (2007). Metodologi Penelitian Kualitatif: Paradigma Baru Ilmu Komunikasi dan Ilmu Sosial.

4. Huberman, A., \& Miles, M. B. (1992). Analisis data kualitatif Terj. Tjetjep Rohidi. Jakarta: UI Press.

5. Winarsih, A. S. (2007). Manajemen Pelayanan. Yogyakarta: Pustaka Pelajar.

6. Budi, P. S. (2009). Obligasi Daerah. Bandung: Alfabeta.

7. Dwiyanto, A. (2005). Mewujudkan Good governance Melalui Pelayanan. Yogyakarta: Pustaka Pelajar.

8. Thoha, M. (2011). Kepemimpinan dalam manajemen. Jakarta: Raja Grafindo.

9. Deddy, M. (2005). Ilmu Komunikasi Suatu Pengantar. Bandung: PT Remaja. Rosdakarya.

10. Thoha, M. (2002). Perilaku Organisasi Konsep Dasar dan Aplikasinya. Jakarta: Grafindo Persada.

11. Moenir. (2006). Manajemen Pelayanan Umum di Indonesia. Jakarta: PT. Bumi. Aksara. 